\title{
Aplikasi Arsip Induk Langganan (AIL) PT. PLN (Persero) Rayon Pelaihari Cabang Banjarmasin Berbasis Web
}

\author{
Sri Rahayu Ningsih ${ }^{1)}$, Wan Yuliyanti ${ }^{2)}$ \\ ${ }^{1) 2)}$ Jurusan Teknik Informatika, Politeknik Negeri Tanah Laut \\ Jl. A. Yani Km 6 Pelaihari Tanah Laut Kalimantan Selatan \\ Telp. (0512) 2021065 \\ ${ }^{1)}$ E-mail: ayueluv@gmail.com \\ ${ }^{2)}$ E-mail:wanyuliyanti@gmail.com
}

\begin{abstract}
Abstrak - Pesatnya perkembangan teknologi membuat perusahaan-perusahaan memperbaharui sistem yang berjalan secara konvensional menjadi terkomputerisasi. Sebagai contoh PT. PLN (Persero) Rayon Pelaihari Cabang Banjarmasin yang dalam proses pencarian data pelanggan masih dilakukan secara manual. Akibatnya sulit melakukan pencarian data pelanggan, memerlukan waktu lama dalam pencarian data dan pengelolaan data, bahkan memiliki resiko kehilangan data pelanggan. Pencarian data dapat dilakukan secara terkomputerisasi menggunakan sistem basis data sebagai tempat penyimpanan data, sehingga dapat mempercepat dan mempermudah dalam pencarian data dan pengelolaan data. Sistem basis data tidak hanya digunakan sebagai tempat penyimpanan, tetapi juga memberikan kecepatan dan kemudahan dalam mencari data, dapat menampilkan data yang akurat, untuk keamanan data yang lebih efesien, dan lain-lain. Tentu hal ini menjadi solusi untuk mempercepat dan mempermudah dalam proses pencarian dan pengelolaan data karena aplikasi ini menggunakan bahasa pemrograman PHP dan MySql sebagai database. Data pelanggan ini dapat langsung di-download dalam bentuk pdf. Melalui aplikasi arsip induk langganan (AIL) berbasis web, pencarian data pelanggan pada PT. PLN (Persero) khususnya Rayon Pelaihari Cabang Banjarmasin akan lebih efektif dan efisien.
\end{abstract}

Kata Kunci : Arsip Induk Langganan, Pencarian Data, Sistem Basis Data

\section{PENDAHULUAN}

Perkembangan ilmu pengetahuan terutama di bidang teknologi dan informasi mengakibatkan perubahan yang sangat besar dalam hal penerapan sistem informasi dalam berbagai bidang, perubahanperubahan yang terjadi ini lebih pada kebutuhan manusia yang menginginkan kecepatan dan ketepatan dalam memperoleh informasi-informasi yang dibutuhkan. Kemajuan teknologi informasi yang begitu pesat ini menuntut berbagai instansi untuk bisa mengikuti perkembangan. Upaya yang dilakukan guna mengikuti perkembangan yang terjadi yaitu dengan memanfaatkan teknologi jaringan komputer khususnya internet, penerapan berbagai pekerjaan ke dalam sebuah aplikasi, dan sebagainya.

Melalui aplikasi, informasi dapat diperoleh lebih mudah dan cepat sehingga perusahaan siap bersaing dan dapat meningkatkan mutu di berbagai bidang, salah satu contohnya yaitu dalam bidang pengarsipan data pelanggan, sistem informasi pada pengeloaan pengarsipan di sebuah perusahaan juga dapat memberikan informasi berupada data arsip.

Kearsipan adalah suatu proses mulai dari penciptaan, penerimaan, pengumpulan, pengaturan, pengendalian, pemeliharaan dan perawatan serta penyimpanan warkat menurut sistem tertentu, sehingga saat dibutuhkan dapat cepat dan tepat ditemukan (Elqorni, Ahmad. 2012).

Proses Pengarsipan di lingkungan PT. PLN (Persero) Rayon Pelaihari Cabang Banjarmasin merupakan suatu proses yang mendukung kinerja PLN dalam bidang pencarian data pelanggan, dimana proses tersebut dimulai dari pengarsipan oleh bagian terkait sampai arsip yang sudah lengkap digudangkan. Proses pengarsipan akan memudahkan pegawai dalam mencari data arsip pelanggan.

Pencarian data pada sistem kearsipan pelanggan di lingkungan PT. PLN (Persero) Rayon Pelaihari Cabang Banjarmasin masih dilakukan secara manual yaitu ketika pegawai tersebut memerlukan satu data pelanggan, maka pegawai tersebut harus mencari satu persatu data pelanggan menggunakan ID pelanggan yang sudah digudangkan di gudang Arsip Induk Langganan (AIL) dengan memerlurkan waktu yang sangat lama dan belum terkomputerisasi, sedangkan data yang berhubungan dengan proses tersebut sangat banyak. Kondisi yang ada saat ini kurang efektif dalam proses pencarian data pelanggan karena akan memerlukan waktu pegawai yang cukup lama hanya untuk mencari satu data pelanggan, untuk memudahkan pencarian arsip pelanggan di lingkungan PT. PLN (Persero) Rayon Pelaihari Cabang Banjarmasin diperlukan aplikasi yang bisa membantu proses pencarian arsip pelanggan.

Berdasarkan permasalahan yang ada di PT. PLN (Persero) Rayon Pelaihari Cabang Banjarmasin maka dibuatlah "Aplikasi Arsip Induk Langganan (AIL) PT. PLN (Persero) Rayon Pelaihari Cabang Banjarmasin Berbasis Web". Aplikasi ini menggunakan bahasa pemrograman PHP dan MySql 
sebagai database. Melalui aplikasi ini admin difasiltasi dalam pencarian data hanya dengan mengklik tombol-tombol yang disediakan tanpa harus mencari data di lemari pengarsipan di gudang arsip induk langganan (AIL) pada PT. PLN (Persero) Rayon Pelaihari Cabang Banjarmasin.

\section{LANDASAN TEORI}

\subsection{Pengertian Aplikasi}

Menurut Supriyanto (2005) Aplikasi adalah program yang memiliki aktivitas pemrosesan perintah yang diperlukan untuk melaksanakan permintaan pengguna dengan tujuan tertentu. Aplikasi adalah program atau sekelompok program yang di rancang untuk digunakan oleh pengguna akhir (end user) Salah satu contoh aplikasi komputer yaitu arsip dan website.

\subsection{Pengertian Arsip}

Arsip adalah catatan rekaman kegiatan atau sumber informasi dengan berbagai macam bentuk yang dibuat oleh lembaga, organisasi maupun perseorangan dalam rangka pelaksanaan kegiatan (Maulidi, 2016). Arsip dapat berupa surat, warkat, akta, piagam, buku, dan sebagainya, yang dapat dijadikan bukti sahih untuk suatu tindakan dan keputusan.

Saat ini arsip data pelanggan pada PT. PLN (Persero) Rayon Pelaihari Cabang Banjarmasin tersimpan dalam suatu lemari di gudang arsip induk langganan (AIL).

\subsection{Website}

Nazrul (2013) menyatakan bahwa Website atau situs adalah kumpulan halaman yang menampilkan informasi data teks, data gambar diam atau gerak, data animasi, suara, video dan atau gabungan dari semuanya, baik yang bersifat statis maupun dinamis yang membentuk satu rangkaian bangunan yang saling terkait dimana masing-masing dihubungkan dengan jaringan-jaringan halaman (Hyperlink).

Selanjutnya menurut Nazrul (2013), website bersifat statis apabila isi informasinya tetap, jarang berubah, dan isi informasinya searah hanya dari pemilik website. Bersifat dinamis apabila isi informasi website selalu berubah-berubah, dan isi informasinya interaktif dua arah berasal dari pemilik serta pengguna website.

\section{ANALISIS SISTEM}

\subsection{Analisis Sistem yang Berjalan}

Sistem pencarian data arsip induk langganan (AIL) yang sedang berjalan pada PT. PLN (Persero) Rayon Pelaihari Cabang Banjarmasin saat ini adalah melalui pencarian secara manual yan dilakukan oleh admin dengan mencari satu persatu ID pelanggan yang tersimpan dalam lemari arsip di gudang Arsip Induk Langganan (AIL). Sistem ini kurang efektif dikarenakan kurang efisien dalam pencarian data karena memerlukan waktu yang cukup lama, bahkan data pelanggan yang dibutuhkan tidak dapat di temukan (kehilangan data pelanggan).

Contoh serta gambaran tentang pencarian data pelanggan secara manual dengan mencari satu persatu ID pelanggan pada data arsip induk langganan yang sudah digudangkan di Arsip Induk Langganan (AIL) pada PT. PLN (Persero) Rayon Pelaihari Cabang Banjarmasin dapat dilihat pada Gambar 1 berikut ini:
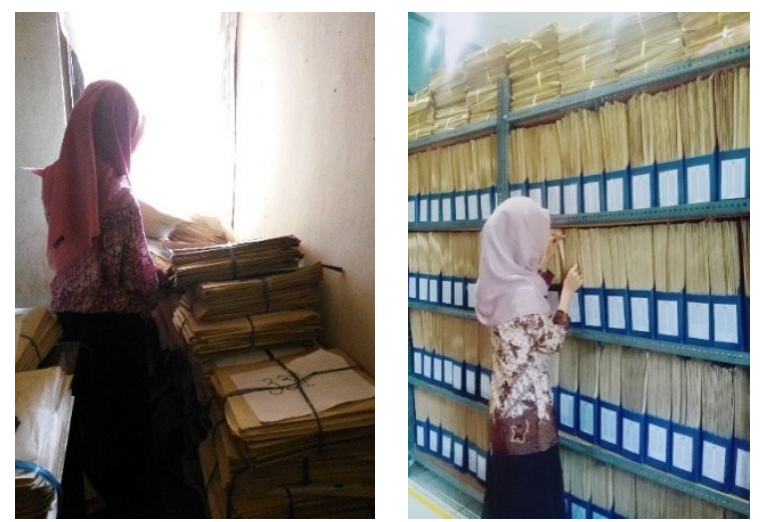

Gambar 1. Pencarian Data Arsip Induk Langganan (AIL)

\subsection{Kerangka Penulisan}

Kerangka penulisan yang digunakan dalam merancang aplikasi ini dapat dilihat pada Gambar 2.

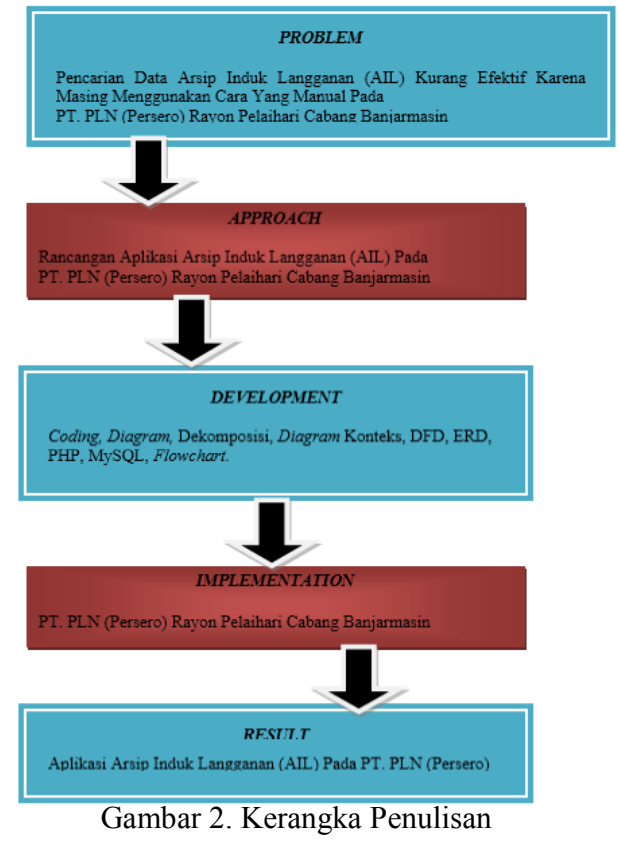

\subsection{Alat dan Bahan}

Alat penelitian yang digunakan dalam penelitian ini adalah Software (Perangkat Lunak), Hadrware (Perangkat Keras), bahasa pemrograman, dan Framework yang digunakan di dalam penelitian:

\section{Hardware}

Adapun hardware (perangkat keras) laptop yang digunakan dalam pembuatan aplikasi ini adalah:

a. Laptop dengan Processor Intel I3 M380 $2.5 \mathrm{GHz}$ 
b. Laptop dengan $R A M 4$ GB

c. Modem

d. $H D D 500 G B$

2. Software

Adapun software (perangkat lunak) yang digunakan dalam pembuatan aplikasi ini adalah :

a. $\quad$ Sistem Operasi Windows 1064 bit

b. Mozila Firefox, Chrome atau Microsoft Edge sebagai browser

c. Xampp

d. Tool antarmuka design Microsoft Visio 2013

e. Notepad ++ atau Sublime Text

\section{Bahasa Pemrograman}

Adapun bahasa pemrograman yang digunakan dalam pembuatan aplikasi ini adalah :
a. $H T M L$
b. $P H P$
c. $C S S$
d. $M y S Q L$

\section{DESAIN DAN IMPLEMENTASI SISTEM}

\subsection{Perancangan Sistem}

\subsubsection{Relasi Entity Relationship Diagram (ERD)}

Menurut Sutanta (2011) Entity Relationship Diagram (ERD) merupakan suatu model data yang dikembangkan berdasarkan objek. ERD pada Aplikasi Arsip Induk Langganan terlihat pada gambar 4 berikut ini:

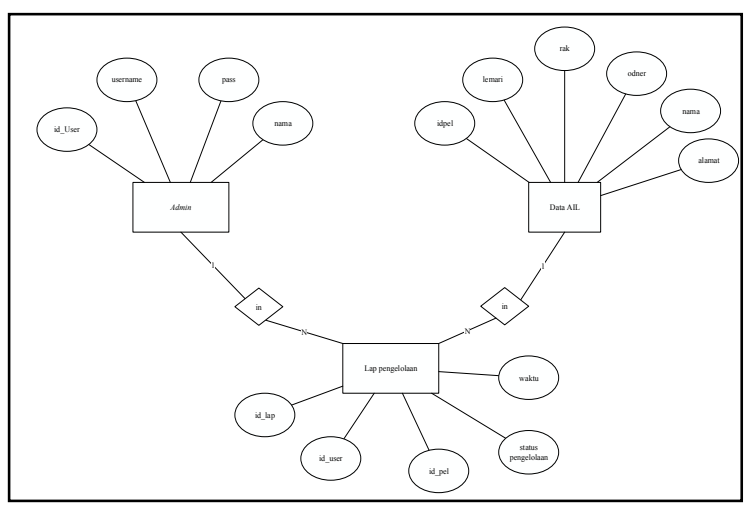

Gambar 3. Entity Relation Diagram (ERD)

\section{Keterangan:}

Admin dapat mengelola data arsip induk langganan (AIL) dan data laporan pengelolaan. Ketika Admin menginputkan beberapa data yang akan ditambahkan ke dalam data pelanggan, maka data akan masuk ke dalam data arsip induk langganan (AIL), dan secara otomatis data AIL tersebut akan masuk ke dalam laporan pengolaan data arsip induk langganan (AIL).

\subsubsection{Data Flow Diagram (DFD)}

Rosa A. S. dan M. Shalahuddin (2013) dalam bukunya menyatakan bahwa: Data Flow Diagram (DFD) atau dalam bahasa Indonesia menjadi Diagram Alir Data (DAD) adalah representasi grafik yang menggambarkan aliran informasi dan transformasi informasi yang diaplikasikan sebagai data yang mengalir dari masukan (input) dan keluaran (output).

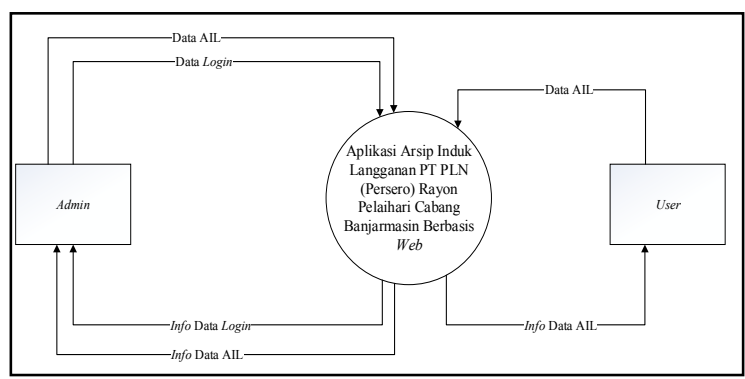

Gambar 4. Diagram Konteks

Aplikasi ini memiliki dua hak akses yaitu Admin dan User, dimana Admin memiliki hak akses untuk mengelola semua data AIL, sedangkan User hanya memiliki hak untuk melihat data AIL, mensearch dan mendownload data AIL.

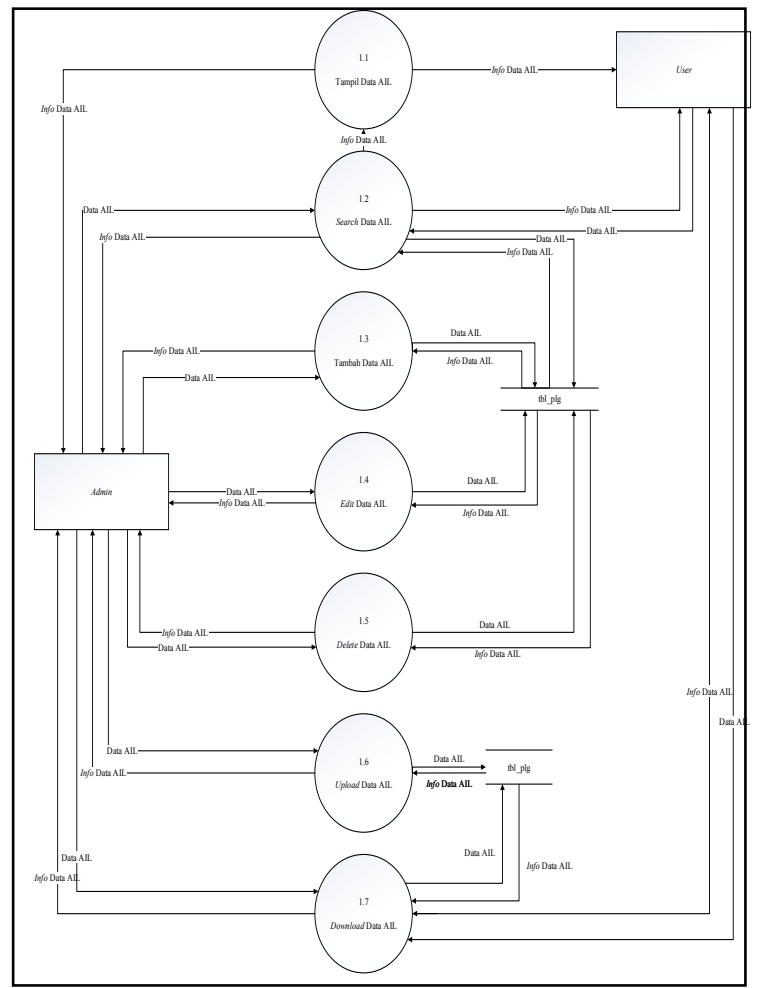

Gambar 5. Data Flow Diagram Level 1 Proses 3 mengelola data AIL

Aplikasi ini terdiri dari beberapa sistem, dan setiap sistemnya terdiri dari sub sistem yang hanya Admin yang bisa mengelola setiap sistemnya, user hanya memiliki hak untuk melihat data AIL, mensearch dan mendownload data AIL tersebut.

\subsubsection{Flowchart}

Flowchart adalah gambaran dalam bentuk diagram alir dari algoritma-algoritma dalam suatu program, yang menyatakan arah alur program tersebut. Flowchart meggambarkan urutan logika dari suatu prosedur pemecahan masalah, sehingga flowchart 
merupakan langkah-langkah penyelesaian masalah yang dituliskan dalam simbol-simbol tertentu Sitorus (2015).

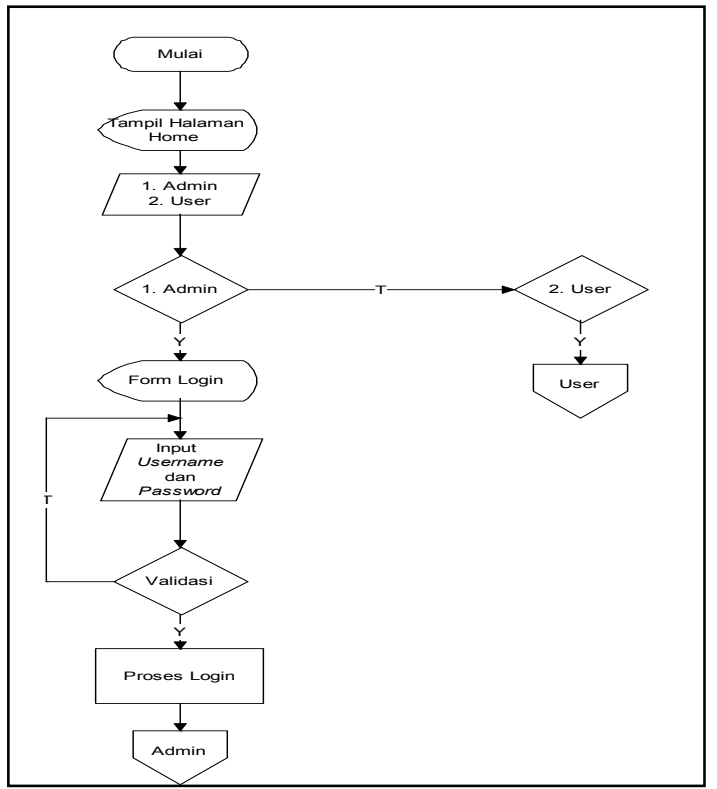

Gambar 6. Flowchart Menu User dan Login Admin

Pertama admin dan masuk sebagai user pada halaman awal home, jika masuk sebagai admin, maka admin akan memasukkan password dan username nantinya akan terverifikasi, jika benar maka akan masuk form menu utama admin. Jika gagal, maka kembali ke proses input username dan password.

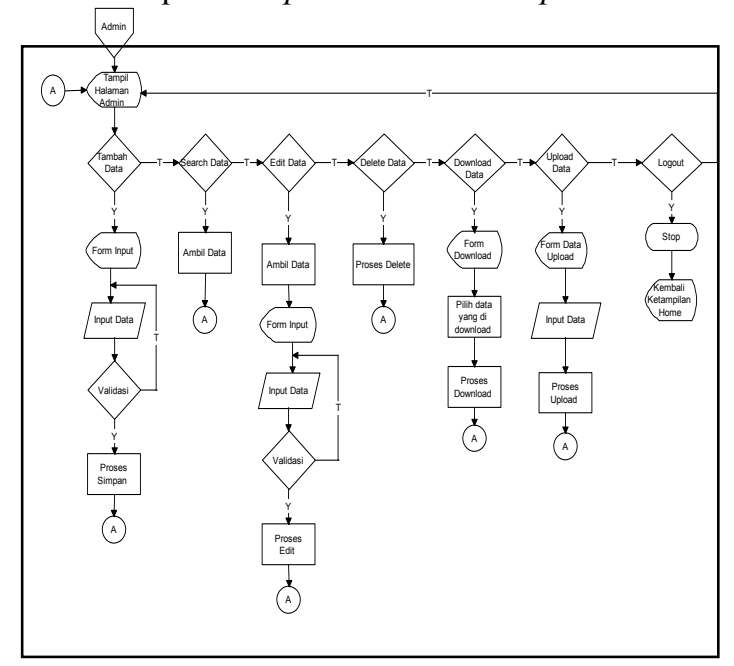

Gambar 7. Flowchart Menu Admin

Ketika telah memasuki form admin maka akan diberikan tampilan seperti admin dapat menambah data pelanggan, mensearch data pelanggan, mengedit data pelanggan, mendelete data pelanggan, mendownload data pelanggan dan mengupload data pelanggan. Terdapat proses loguout untuk kembali kehalaman awal aplikasi yaitu home.

\subsection{Implementasi}

Implementasi dalam penggunaan aplikasi ini dapat dilihat pada gambar-gambar di bawah ini:

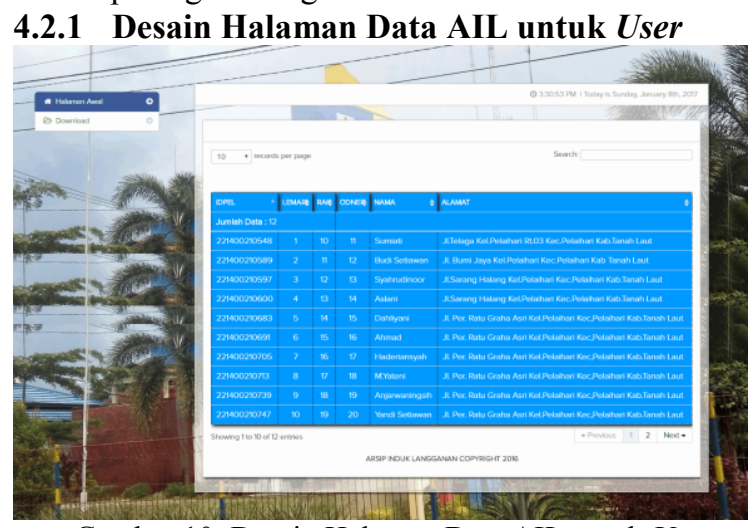

Gambar 10. Desain Halaman Data AIL untuk User

\subsubsection{Desain Halaman Download User}

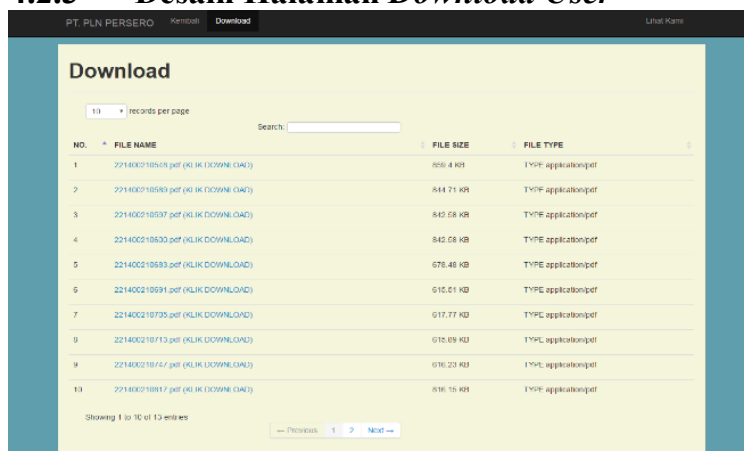

Gambar 11. Desain Halaman Data AIL untuk User

\subsubsection{Desain Halaman Login}

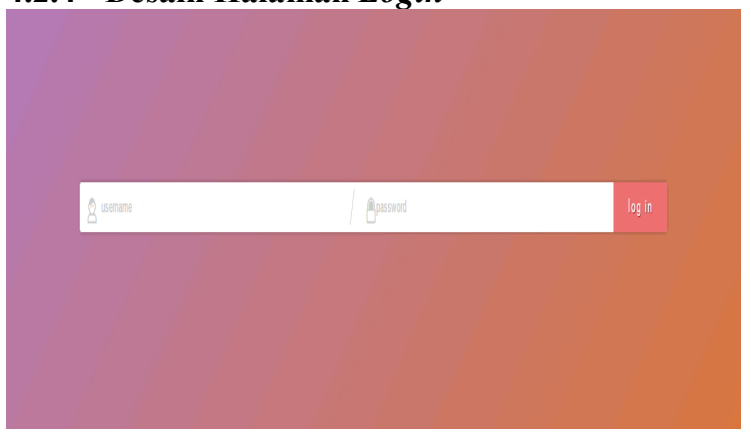

Gambar 13. Desain Halaman Login

\subsubsection{Desain Halaman Panel $A d m i n$}

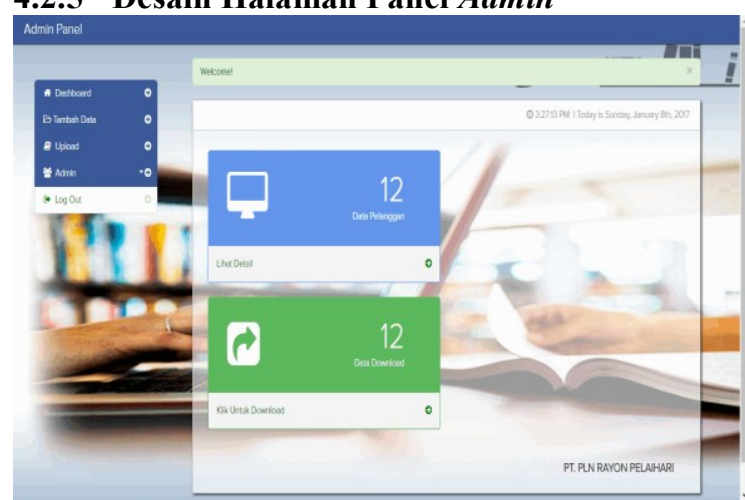

Gambar 14. Desain Halaman Panel Admin 


\subsubsection{Desain Halaman Lihat Data AIL}

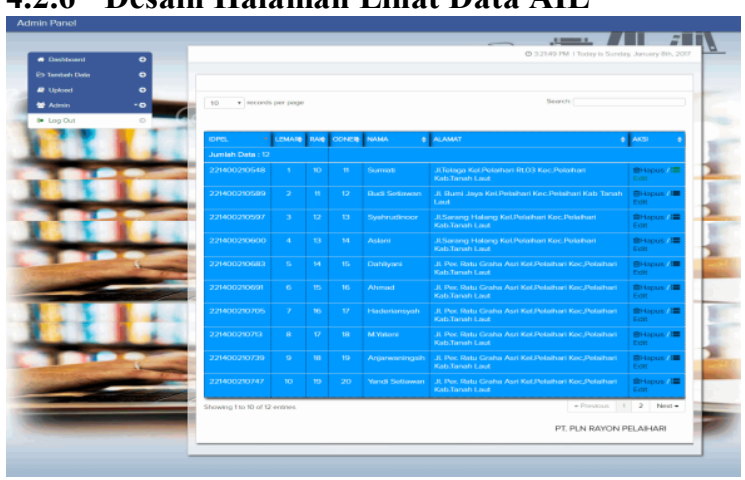

Gambar 15. Desain Halaman Lihat Data AIL

\subsubsection{Desain Halaman Edit}

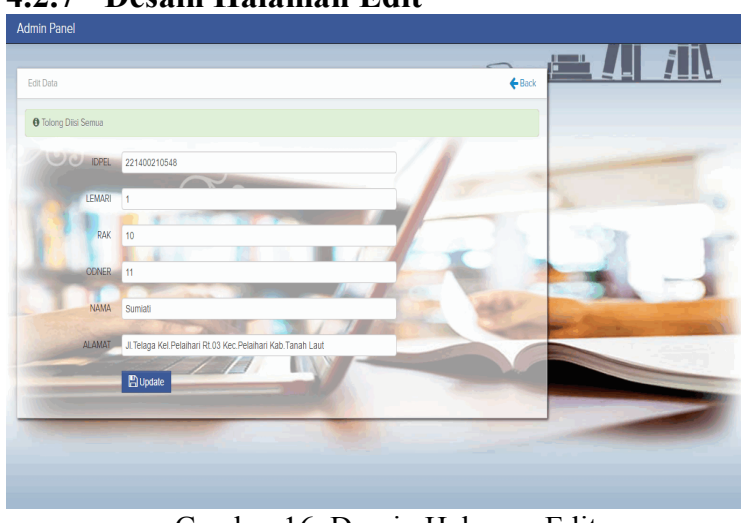

Gambar 16. Desain Halaman Edit

\subsubsection{Desain Halaman Download Admin}

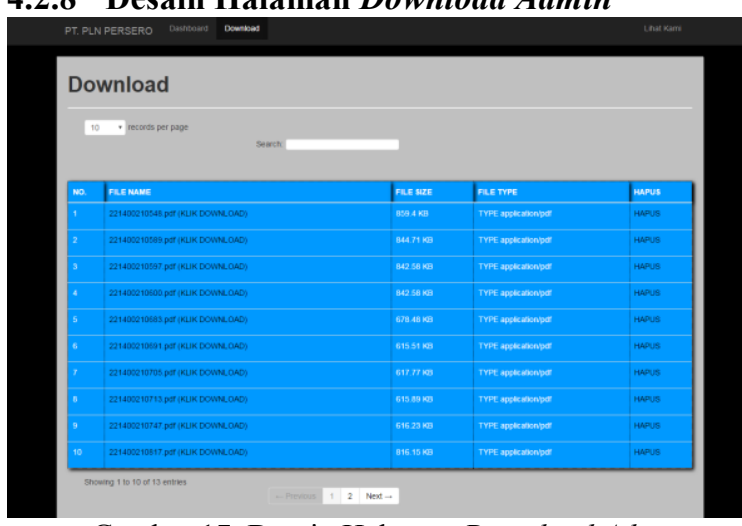

Gambar 17. Desain Halaman Download Admin

\subsubsection{Desain Halaman Tambah Data}

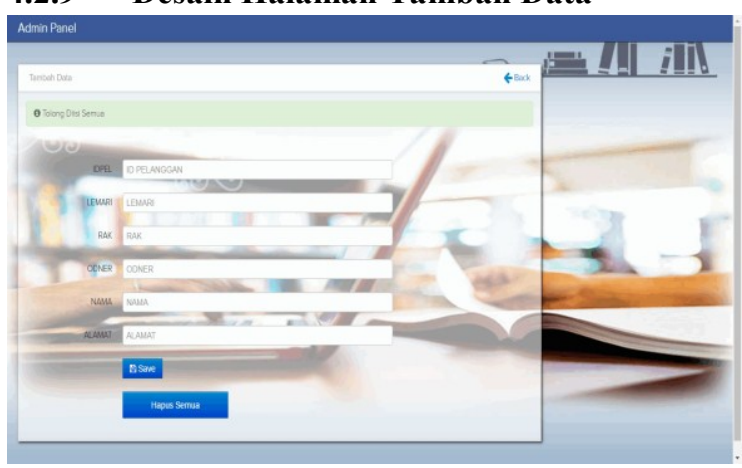

Gambar 18. Desain Halaman Tambah Data

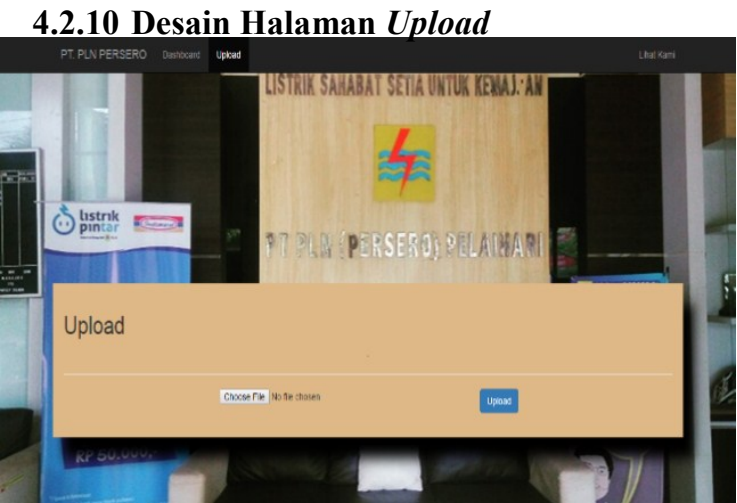

Gambar 19. Desain Halaman Upload

\subsubsection{Desain Halaman Tambah Admin}

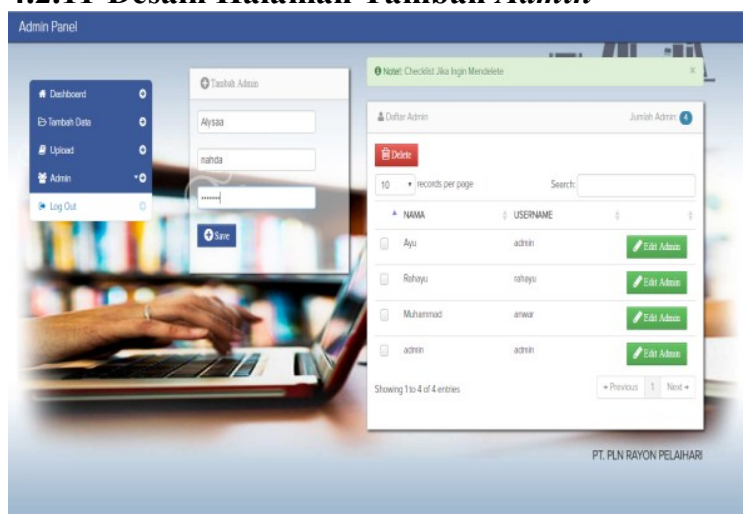

Gambar 20. Desain Halaman Tambah Admin

\subsubsection{Desain Halaman Edit Admin}

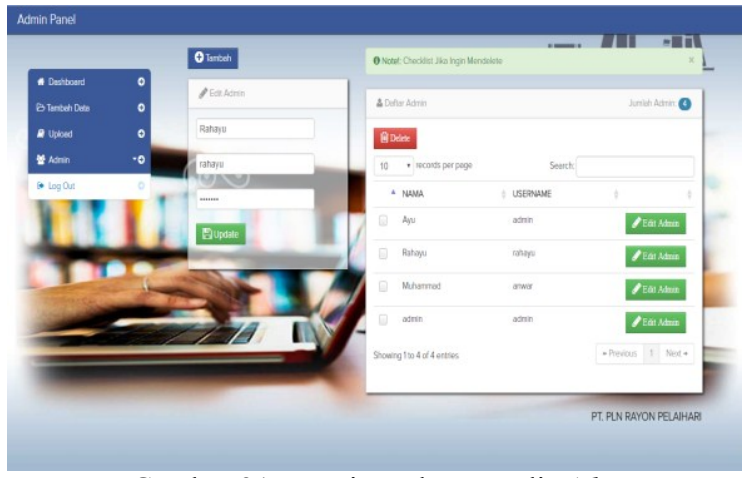

Gambar 21. Desain Halaman Edit Admin

\section{Penutup}

\subsection{Kesimpulan}

Kesimpulan yang diperoleh berdasarkan pembahasan pada BAB I - BAB IV dapat di simpulkan bahwa:

Aplikasi Arsip Induk Langganan (AIL) di PT. PLN (persero) Rayon Pelaihari Cabang Banjarmasin merupakan fasilatas bagi admin dalam meningkatkan efisiensi dan efektifikas kerja terutama dalam pengarsipan data, pencarian data, pengeloaan data serta penyimpanan data arsip induk langganan (AIL) yang diharapkan mampu menggantikan sistem yang sedang berjalan, yaitu sistem pengarsipan serta pencarian data secara manual antara lain dengan mencari langsung data yang dibutuhkan di lemari di 
gudang arsip induk langganan (AIL) di PT. PLN (persero) Rayon Pelaihari Cabang Banjarmasin.

\subsection{Saran}

Pembuatan Aplikasi Arsip Induk Langganan (AIL) ini masih memiliki banyak kelemahan, penulis berharap ada penulis lain yang mau mengembangkan yaitu membuat sistem pengarsipan data yang lebih terintegrasi.

\section{DAFTAR PUSTAKA}

A.S., Rosa Shalahuddin, M. 2013. Rekayasa Perangkat Lunak Terstruktur dan Berorientasi Objek. Informatika: Bandung

Elqorni, Ahmad. 2012. Pengertian Kerasipan dan Beberapa Peranan Penting dari Kearsipan. Diakses dari URL: https://elqorni.wordpress.com/category/manajem en-kantor/arsip-dan-dokumen/

Kusuma, Winda Febriani. 2015. Pengembangan Halaman Web Menggunakan XML Dalam Perkembangan Web 2.0. Jakarta: Jurnal Teknik Informatika Universitas Gunadarma.

Maulidi, Achmad. 2016. Pengertian Arsip dan Kearsipan. Diakses dari URL: https://www.kanalinfo.web.id/2016/09/pengertia n-arsip-dan-kearsipan.html

Nazrul, Achmad, 2013. Rancangan Website dan Profil Usaha Advertising Menggunakan PHP dan MySQL. AMIK SIGMA Palembang. Jurnal.
Sitorus, L. 2015. Algoritma dan Pemrograman. Yogyakarta: Penerbit Andi. Supriyanto, Aji. 2005. Pengantar Teknologi Informasi. Salemba Infotek: Jakarta.

Sutanta, Edhy. 2011. Basis Data Dalam Tinjauan Konseptual. Andi Offset: Yogyakarta.

\section{Biodata Penulis}

Sri Rahayu Ningsih, Lahir di Kota Amuntai pada tanggal 09 Nopember 1996. Penulis pertama menyelesaikan Sekolah Menengah Atas di SMKN 1 Pelaihari mengambil Konsentrasi Jurusan Administrasi Perkantoran, Lulus pada Tahun 2014 dan melanjutkan pendidikan ke Politeknik Negeri Tanah Laut. Saat ini penulis kedua telah menempuh semester IV di Jurusan Teknik Informatika Politeknik Negeri Tanah Laut dan sedang menyelesaikan Tugas Akhir untuk memperoleh gelar A.Md. E-mail : ayueluv@gmail.com dan nomor telepon : 08235896 3339

Wan Yuliyanti, meraih gelar Sarjana Pendidikan (S.Pd) Program Studi Pendidikan Bahasa Inggris dari Universitas Tanjungpura Pontianak dan menyelesaikan Magister Pendidikan (M.Pd) pada Program Studi yang sama dari Universitas Palangka Raya. Menjadi dosen Bahasa Inggris di Politeknik Negeri Tanah Laut sejak 2009 pada Program Studi Teknik Informatika sampai saat ini (2017). E-mail : wanyuliyanti@gmail.com dan nomor telepon : 0813 16889967. 